\title{
Trust and Control in Public Sector Reform Complementarity and Beyond
}

\author{
Vallentin, Steen; Thygesen, Niels Thyge
}

Document Version

Accepted author manuscript

Published in:

Journal of Trust Research

DOI:

$10.1080 / 21515581.2017 .1354766$

Publication date:

2017

License

Unspecified

Citation for published version (APA):

Vallentin, S., \& Thygesen, N. T. (2017). Trust and Control in Public Sector Reform: Complementarity and

Beyond. Journal of Trust Research, 7(2), 150-169. https://doi.org/10.1080/21515581.2017.1354766

Link to publication in CBS Research Portal

\section{General rights}

Copyright and moral rights for the publications made accessible in the public portal are retained by the authors and/or other copyright owners and it is a condition of accessing publications that users recognise and abide by the legal requirements associated with these rights.

Take down policy

If you believe that this document breaches copyright please contact us (research.lib@cbs.dk) providing details, and we will remove access to the work immediately and investigate your claim. 


\title{
Trust and Control in Public Sector Reform: Complementarity and Beyond
}

\author{
Steen Vallentin and Niels Thyge Thygesen \\ Journal article (Accepted manuscript*)
}

Please cite this article as:

Vallentin, S., \& Thygesen, N. T. (2017). Trust and Control in Public Sector Reform: Complementarity and Beyond. Journal of Trust Research, 7(2), 150-169. D0I: 10.1080/21515581.2017.1354766

This is an Accepted Manuscript of an article published by Taylor \& Francis in Journal of Trust Research on 01 Aug 2017, available online:

D0I: http://www.tandfonline.com/10.1080/21515581.2017.1354766

* This version of the article has been accepted for publication and undergone full peer review but has not been through the copyediting, typesetting, pagination and proofreading process, which may lead to differences between this version and the publisher's final version AKA Version of Record.

Uploaded to CBS Research Portal: January 2019 


\section{Trust and Control in Public Sector Reform: Complementarity and Beyond}

\section{Abstract}

This paper provides an analysis of trust-based management reform in the Danish public sector from the point of view of the trust-control nexus. Based on a qualitative case study of home care in the municipality of Copenhagen we argue that a complementary view of trust and control is superior to a substitution view when it comes to accounting for public sector reform as structure and process. Also, we propose a widening of the theoretical lens in the form of an emergent view of how trust and control, instead of being beforehand determinable and more or less stable identities, emerge in multiple and singular ways from multiple events in the organization. Noticing a dearth of research that explicitly addresses trust issues with regard to public sector management and organization, the paper is a response to the call for more studies of trust as an institutionally embedded phenomenon.

\section{Introduction}

The performance, management and future development of the public sector are matters of great concern to society at large. The funding, quality and availability of public services in areas such as health care, social security and education are thus subject to constant debate among politicians, union- and employer representatives, experts, public managers and employees and the citizens (all of us) that rely on the provision of public services. In recent years, trust has become a vital issue in this debate, often promoted as a positive counter-image to - and relief from - the negatives associated with distrust and control. Bouckaert (2012b) suggests that we can speak of three types of relationships with regard to the public sector and trust: 1) trust of 
citizens and organizations toward government and the public sector (see also Høyer \& Mønness, 2016; Van de Walle et al., 2008; European Commission, 2017; OECD, 2017); 2) trust of government and the public sector toward citizens and organizations; 3) trust within government and the public sector (see also Edelenbos \& Eshuis, 2012). While public administration research has predominantly been concerned with the first type of relationship (Bouckaert, 2012b), our focus is the third type: the internal workings of trust and how trust is woven into efforts to make organizational change happen in the public sector.

In some countries with strong welfare legacies, like Denmark, Sweden and Norway trust has become a label for a new brand of reform aiming to de-bureaucratize and decentralize the public sector while, ideally, paving the way for more trusting relationships to develop between managers and employees and between different public functions and institutions. Along with other managerial concepts stressing the value of relationship-building, such as social capital and co-creation, the focus on trust can furthermore be seen as an integral part of public sector efforts to reach out to civil society and engage volunteers - and thus networks - in collaborative production and delivery of services (cf. Adler \& Kwon, 2002; Andrews, 2010; Andrews \& Brewer, 2013; Gittell \& Douglass, 2012; Gouillart \& Hallett, 2015, Six \& Sorge, 2008). In this paper, we present an analysis of burgeoning trust reform based on the Danish case. More specifically, we provide an empirical analysis focusing on the area of home care within the Municipality of Copenhagen. Home care has often been singled out as the very epitome of New Public Management run amok, that is, a low-skilled service area besieged by management control, documentation requirements and monitoring. However, concrete steps have been taken in the municipality, as part of the trust agenda, to give more freedom to employees in home care and give them more room to exercise their professional expertise and judgment at work. 
Internal trust reform may for the time being be a particular Scandinavian phenomenon that to some extent reflects the high-trust conditions prevailing in the Scandinavian countries (Fukuyama, 1995). However, the turn to trust in these settings is motivated by a more general concern: widespread discontent with decades of public sector reform dominated by the philosophy/ideology of New Public Management (NPM). Hood \& Dixon (2015a) have recently presented an analysis of three decades of successive NPM-style reforms in the UK (for many the vanguard state of NPM). They conclude that while NPM was ostensibly meant to create 'a government that works better and costs less' it has instead led to higher costs and more complaints. With its firm focus on managing performance and measuring performance outcomes and its insistence that disaggregation and competition in public services are conducive to lower costs and higher quality, NPM-type measures have had deeply negative effects on many important administrative values. Indeed, with their excessive emphasis on cost cutting, NPM reforms have not only been blind to the value of cooperation across public agencies, thus undermining trust (Jun, 2009), they have also, according to Hood \& Dixon, “damaged some traditional and important “Weberian' qualities of administration such as fairness and consistency" (2015b, p. 265).

Damage to trust - and other values associated with the 'warm hands' of public welfare (Clarke \& Newman, 1997) - is part and parcel of the general critique of NPM for being too reliant upon a managerial and instrumental mindset (Christensen \& Lægreid, 2007; Pollitt \& Bouckaert, 2011). And trust is looming large as an international concern regarding the public sector and its relations to civil society, as reflected in recent reports from the European Commission (2017) and OECD (2017). NPM is, however, implemented differently in different countries, and public sector reform strategies invariably reflect the unique political, institutional, 
economic and cultural conditions and legacies of particular countries (Jun, 2009). In this respect, any national case will be a special case. The Danish case is special in the sense that problems of (dis)trust have been explicitly problematized by national and local governmental bodies and have become manifest in reform efforts promoting trust as a matter of positively improving the management and performance of public sector organizations (as opposed to, for instance, combat negatives of intransparency and corruption). In this as well as in other welfare-related areas, the Danish case can serve as a template and provide inspiration for public sector reform in other countries. Similar reform efforts are underway in neighboring countries Sweden and Norway inspired by the Danish experience.

We approach trust reform from the point of view of the trust-control nexus (BijlsmaFrankema \& Costa, 2005; Das \& Teng, 2001; Möllering, 2005). Hence, we concur with Edelenbos \& Eshuis, who argue that "one-sided attention to either control or trust does not do justice to the complexity of the practice of public management. In practice, public managers have to deal with the complex interplay between trust and control all the time" $(2012$, p. 651). We present a two-pronged argument with regard to this nexus. First, we argue for the analytical value of seeing trust and control not as substitutes but in more complementary and mutually constitutive terms. We contend that we run the risk of providing a too idealist and/or reductionist view of public reform efforts if we turn them into a matter of replacing control with trust. Second, rather than just provide an affirmation of the complementary view, we also want to test and challenge it through our empirical analysis. Hence, our case study is guided by a complementary understanding of trust and control while at the same time remaining open to the possibility that we need to transcend this in order to properly capture what is going on in practice. 
Noticing a dearth of research that explicitly addresses the trust-control nexus (Edelenbos \& Eshuis, 2012; Grey \& Garsten, 2001) or trust as such (Bouckaert, 2012a, 2012b; Le Grand, 2010; Oomsels \& Bouckaert, 2014; Van de Walle, 2011, 2017) in a public sector context, the aim of the paper is to provide a nuanced and critical empirical analysis of public sector reform based on trust and to add to our knowledge of what such reform efforts can entail and produce, both in structural and process terms. In this respect, it is a response to the call for more studies to address trust as an institutionally embedded phenomenon (Bachmann, 2011). The theoretical aim and contribution of the paper is to challenge and look for ways to transcend the complementary view and to argue for the value of what we will refer to as an emergent view of trust and control.

We proceed to provide an empirical background for our analysis, i.e., a broad outline of trust reform as it has developed in Denmark. In the theory section we outline the substitution and complementary views of the trust-control nexus and briefly discuss the prospects of venturing beyond them. We also briefly outline the theoretical properties of trust and control as embedded phenomena within the setting of public sector management and organization. Our empirical analysis, preceded by a methodology section, is a qualitative study of trust reform in home care and what it entails in regard to relations between trust and control.

\section{Trust reform in Denmark}

Although there have been earlier rumblings of discontentment over the ways and implications of NPM in Denmark, the trust agenda got its first formal thrust forward after the parliamentary election and change of government in 2011 . The newly elected government, led by the Social Democrats with support from the Social Liberals and the Socialist People's Party made trustbased reform of the public sector an explicit priority. The Danish government platform of 
October 2011 thus speaks of a pressing need to de-bureaucratize the public sector - in order to counteract many years of growing bureaucracy and state control over municipalities in particular. Controls that do not directly benefit the purpose of providing value for citizens should be abandoned and this should leave more room for trust to develop and be an asset (Den danske regering, 2011). In June 2013, symptomatic of the Danish tradition of corporatism, cross-sector dialogue and labour market negotiation, the trust agenda became part of a collective agreement between national government, Local Government Denmark (Kommunernes Landsforening - the national advocacy organization of Danish municipalities), Danish Regions (the interest organization for the regions, which are mainly responsible for the provision of hospital services) and three labour unions - Akademikerne, FTF and OAO. This agreement, which addresses the need for modernization of the public sector and proposes that "management and governing should have trust and responsibility as their point(s) of departure", has subsequently been referred to as the trust reform.

At the time of writing, Denmark has a three-party, Liberal-Conservative government, and the government platform of November 2016 maintains the focus on trust and the need to simplify rules and procedures in the public sector in order to allow public employees to focus more on their core tasks and less on documentation and paperwork. It is, however, important to mention that while de-bureaucratization of the public sector remains on the agenda of national government, it is challenged by other policy prerogatives that tend to point in other directions and often turn out to have greater leverage. Trust is but one of several reform agendas to which public organizations and their managers and employees are continuously subjected. Furthermore, both the collective agreement and the policy priorities of the current government suggest that 
trust-as-reform-tool is a complement to rather than a substitute for existing models of management and control. The same institutional pattern is seen in local policy making.

The Municipality of Copenhagen is so far leading the way among public organizations when it comes to addressing the relevant trust issues in a programmatic fashion. Hence, in its budget agreement for 2013 the political leadership vowed to "remove all unnecessary controls and bureaucracy" and give employees more freedom and time to carry out their core tasks (instead of filling out forms and documenting their activity for control purposes, etc.) (Københavns Kommune, 2012, p. 69). According to this document, the Municipality of Copenhagen is setting an explicit trust agenda and striving to create rule-free areas and trustful spaces for its managers to manage and its employees to self-manage (aims that have been reaffirmed in the budget agreement for 2014 and in other more recent communications). However, it is also clearly stated that the turn to trust is not about removing all rules and control requirements. The purported aim is to get rid of 'unnecessary controls' - however they may be defined and separated from supposedly 'necessary' ones.

\section{The trust-control nexus: substitution, complementarity and beyond}

As a theoretical and analytical starting point for understanding these developments, we concur with Luhmann (1979) and Lewis \& Weigert (1985) when they argue that trust must be considered "an irreducible and multidimensional social reality" (Lewis \& Weigert, 1985, p. 967). To apply a socio-analytical lens is to insist that trust is a property of collective units and applicable to relations among people rather than psychological states taken individually (Lewis \& Weigert, 1985). This means that we emphasize relational and situational (as opposed to dispositional) antecedents of trust; that is, we consider how trust (or distrust) is a product of past 
direct and indirect experiences between different parties and how the development of trust is contingent upon the uncertainties and risks that are involved in situational encounters (Gargiolu \& Ertug, 2006).

To call for more research to address trust issues in the public sector is not to suggest that trust in this context differs fundamentally from trust in other organizational/managerial settings. Here, as elsewhere, we can speak of the prevalence of institution-based, calculus-based and relational trust (Rousseau et al., 1998). However, a socio-analytical lens alerts us to the fact that these basic forms of trust are not just reflective of individual (psychological) predispositions. They are embedded in particular ways in the history and development of public governance. The three forms are institutionalized in the classical or Neo-Weberian model of public administration (institution-based) and in the modes of governing associated with New Public Management (calculus-based) and New Public Governance (relational) (Bouckaert, 2012a, 2012b; Osborne, 2006). Hence, it is the interplay of different embedded forms of trust that we need to understand better - ranging from politicized conflict between different views to the emergence of hybrid organizational forms. While we can speak of such embeddedness on the level of archetypes of governance (vis-à-vis the Neo-Weberian model of bureaucracy, NPM and NPG), we also need to study how trust-based initiatives are actually brought to bear in practice and what impact they have on the micro level of organization. This is our primary concern in this paper. That being said, trust is a topic that is often neglected by public management/administration scholars. One explanation for this is a tendency in political science to define trust as naïve and unconditional while considering scepticism and distrust as positives (Six, 2013; e.g. Le Grand, 2010; Krouwel $\&$ Abts, 2007). To focus on the trust-control nexus is, as we see it, an effective way to flesh out the pros as well as the cons of trust in a more nuanced and sociologically informed manner. 
By providing an analysis of public sector reform from the point of view of the trust-control nexus (Bijlsma-Frankema \& Costa, 2005; Das \& Teng, 2001; Möllering, 2005), we are tapping into one of the main queries in the trust literature: whether trust and control should be considered substitutes or in more complementary or mutually constitutive terms (Bijlsma-Frankema \& Costa, 2005; Das \& Teng, 1998; Inkpen \& Currall, 2004; Khodyakov, 2007; Möllering, 2005; Sitkin, 1995; Sitkin \& George, 2005; Six, 2013; Zucker, 1986).

Although closely intertwined with control, trust is fundamentally different from control in terms of how it reduces complexity. Trust, on the one hand, reduces complexity - and enables action - by making a bet on a positive future outcome and excluding negative possibilities from consideration (Luhmann, 1979). Trust constitutes a 'leap of faith' or a suspension of disbelief in the face of risk and uncertainty (Möllering, 2006), and entails the acceptance of a certain measure of vulnerability on the part of the trustor in relation to trustees (Baier, 1986; Mayer et al., 1995). Control, on the other hand, reduces complexity by regulating and reducing the number of possible outcomes (Edelenbos \& Eshuis, 2012). In sum, we define trust as decisions and actions based on perceived risk, and control as efforts to minimize uncertainty.

Supporting a substitution view, some research has shown that formal control mechanisms, involving the codification, monitoring and safeguarding of social relations, can undermine or chase out trust, while other contributions have pointed to situations in which trust seems to remove the need for control (Bijlsma-Frankema \& Costa, 2005; Khodyakov, 2007). In relation to public management, the substitutive view implies that legal and social governance are placed in opposition to each other, and that strengthening of trust is seen to weaken control and vice versa (Edelenbos \& Eshuis, 2012). However, more and more empirical examples are supporting the view that trust and control are not substitutes, but complements (Six, 2013). This view is 
supported by theory development as well as empirical studies (Bijlsma-Frankema \& Costa, 2005; Das \& Teng, 1998; Inkpen \& Currall, 2004; Khodyakov, 2007; Möllering, 2005; Sitkin, 1995; Sitkin \& George, 2005; Six, 2013; Weibel et al., 2016; Zucker, 1986).

We propose that a complementary view has greater value and relevance for an understanding of reform processes in the public sector. Thus, we will argue for the value of considering trust reform not as a matter of replacing control with trust, but as a matter of reconfiguring and balancing intricate relationships between trust and control. Edelenbos and Eshuis (2012) argue that trust and control can co-evolve over time in public organizations; i.e. they can influence and reinforce each other in a symbiotic relationship (as opposed to one characterized by interference). This is supported more broadly by research that recognizes how trust and control both serve to enable the effective functioning of individuals, teams and organizations and how both constitute essential features of organizational life (Costa \& BijlsmaFrankema, 2007; Skinner \& Spira, 2003; Smets et al., 2013). Furthermore, it has been argued that not only informal - social - modes of control (Bradach \& Eccles, 1989) but even formal control mechanisms can be conducive to trust building, the latter "by providing people with objective rules and clear measures on which to base their assessments and evaluations of others" (Bijlsma-Frankema \& Costa, 2005, p. 270; see also Coletti et al., 2005; Das \& Teng, 1998; Long \& Sitkin, 2006; Weibel, 2007). Möllering suggests to consider trust and control as a duality, arguing that "each assume the existence of the other, refer to each other and create each other, but remain irreducible to each other" (2005, p. 284).

To clarify, we will distinguish between two different modes of understanding within the complementary view. First, to consider trust and control as complements means to consider them as different modes of orientation that are both vital for the functioning of organizations and 
which can be mutually supportive. It is also to assume that trust and control constitute relatively stable identities that are determinable beforehand, and which can then be weighed/balanced against each other. Second, to consider trust and control as mutually constitutive is to emphasize how these modes are not just different, but can influence each other, co-evolve and thus have the capacity to change over time. It is to imbue trust and control with a certain amount of plasticity and thus to see them as less stable identities. We cannot take for granted, for instance, that certain structural elements - like the models of governing associated with NPM - are associated with either trust or control (or a certain balance between one and the other) as this may change over time, due to social interactions and learning processes taking place between organizational members.

To apply a complementary or mutually constitutive view of the trust-control nexus is not to take a particular (positive) relationship between the two for granted, but to emphasize their temporal and spatial simultaneity, i.e. how trust and control are interwoven and mutually defining features of social relations in organizations. The same premises apply to our proposed emergent view of how trust and control can interrelate in public sector organization. This view signifies a further step in the direction suggested by the constitutive view, i.e., towards a destabilization of the notion that the identities of trust and control can more or less (vis-à-vis the constitutive view) be determined beforehand. The emergent view suggests that we need to consider how trust and control emerge from multiple and indeterminable events in the organization. With the proposed emergent view, we venture beyond an affirmation of the complementary view (compared to the substitution view) and thus attempt to push the argument further than the established ways of perceiving trust and control. Considering that these considerations are based on a single case study, they remain tentative and are presented here 
mainly as 'a possible step beyond complementarity' and a suggestion for further research. Importantly, we do not question the validity and relevance of the complementary views (or, for that matter, the substitution view), but will seek to flesh out the contours of the emergent view in terms of what the other views fail to account for in our empirical case.

\section{Methodology: A case study of trust reform in home care}

The empirical analysis focuses on the implementation of a new governance model in Home Care (in the Municipality of Copenhagen). Home Care is part of The Health and Care Administration, the municipality's largest in terms of budget and employees. Home Care is engaged in other trust-related initiatives, but we have chosen to focus on the implementation of 'visiting blocks' (see below) because it appears to be the most significant and material initiative driven by the trust agenda so far. Following Bromley, a case study is a "systematic inquiry into an event or a set of related events which aims to describe and explain the phenomenon of interest" (Bromley, 1990, p. 302). The event at the center of our analysis is the new governance model. We aim to describe and explain its relational effects and how it leads to new modes of co-existence between trust and control.

With regard to use of theory, we find inspiration in two different traditions. First, in Yin's (2014) approach to the testing or making probable of (new) theories or assumptions. Second, in Robson's (2002) greater emphasis on theory development. While the former sustains our use of the complementary view as analytical point of departure, the latter underpins our endeavor to transcend this perspective. Which is to say that the case study we present is abductive (Langley, 1999, 2009; Dubois \& Gadde, 2002). It departs from the notion of complementarity as a way to 
conceptualize the phenomenon of interest, and then feeds the findings from the case study into a discussion aiming to further enrich our theoretical understanding.

The case study method is well suited for explorative purposes. In this particular case, it is a matter of understanding the trust-control nexus in process terms. To iterate, what we are concerned with is the effects that de-bureaucratization has on relations between trust and control. In terms of how we approach process as such, we apply what Chia and Langley (2004) have referred to as a 'weak view' (see also Welch \& Paavilainen-Mäntymäki, 2014). This means that we treat process as important, but as being, ultimately, reducible to the action of things. According to a weak view, processes form part of the world under investigation, whereas according to a strong view, the world is process (Hernes, 2008, p. 23 - see also Hernes, 2014). We find additional inspiration in Hernes' effort to overcome the separation between process and entity (substance). Instead of asking whether something is process or entity, we should ask "how it came to take on entitative properties and, furthermore, how those properties feed into processes in turn" (Hernes, 2008, p. 30). This involves an assumption "that something is stable for the sake of analysing it, while allowing for it to become something else" (Hernes, 2008, pp. 30-31). Hence, we will treat the reform effort in question as a mode of de-bureaucratization that we can speak about meaningfully in its own right (as an entity, as a structure, as structural change) while at the same time showing how its modus operandi and various relational effects must be considered in process terms. Following Möllering's (2013) categorization of process views, our analysis will, in particular, emphasize becoming features of trust building - as we show how public sector reform produces new identities and relationships.

The case study is based on qualitative data, written material (various internal documents and communications) and semi-structured interviews, with interviews being the primary data 
source. The main round of interviews was conducted in 2013. This includes interviews with the mayor (the political head of The Health and Care Administration), two home care managers, two internal consultants, one group leader and one local head of visitation. All interviewees had a stake in the trust reform in general and in the new governance model in particular. Our approach to interviewing can be described as critical and constructive in the sense that we sought to challenge ideal notions of trust as well as what makes or breaks efforts to implement trust (Alvesson \& Skjöldberg, 2010). Getting people to speak freely about their experiences of the reform and their concerns about its effects was quite unproblematic as trust is not seen as a panacea to all problems in home care, but rather as one reform element among others to which the organization is subjected or is working to implement. Likewise, our questions concerning trust and control were not a stretch for interviewees, who generally confirmed the analytical relevance of this problematic and showcased a high level of process awareness. Follow-up interviews were conducted in 2016 to follow up on the process and learning that had taken place in the meantime. This includes interviews with a home care manager and a consultant.

The data analysis was conducted as a process supporting the explorative purpose of the case study. After each semi-structured interview new (and sometimes conflicting) insights were extrapolated in notebooks and brought back into the next interview. This process gradually triggered, built and tested new insights regarding the phenomenon of interest. It should be noted that the case study is concerned with the implementation of a reform and consequently the initiative in question has not stabilized entirely and is still subject to adjustments. Furthermore, the data gathering has privileged managerial accounts of the process. We have, for instance, not interviewed home care employees (at the operational level). What we provide, then (vis-à-vis our weak process view), is a more general structural and process account of trust reform in home 
care and what it entails. Hence, when we speak of how home care employees have experienced the reform in question, we are, apart from a few statements taken from internal minutes of meetings, relying on managerial accounts hereof. A stronger process analysis would need to dig deeper into the matter of how the new governance model is experienced by home care employees and, perhaps, users. Furthermore, our empirical material does not allow us to flesh out in detail how the reform has been experienced differently in different parts of the organization.

\section{A case of trust reform in home care}

Our case study of home care is presented in four parts. The first part provides a structural outline of the reform effort in question, whereas the other three parts focus on its relational and process effects on a) home care management/managers, b) home care employees and c) relations between the administrative control function and operations.

\section{Reform as structural change}

Home care in the Municipality of Copenhagen provides health care or supportive care to people in need, in particular senior citizens (aged 65+). Home care has approximately 1,200 employees. It consists of five operational units, covering local boroughs, and 40 operational groups, and makes 8,700 visits to users per day. Home care operates under the auspices of The Health and Care Administration, which has approximately 10,000 employees in all and an annual budget of approximately DKK 6.4 billion (2017).

Provision of home care is organized through an NPM technology that creates an internal market place by separating the ordering and the delivery of services in order to benefit receivers. The Danish term for this is the BUM model (Bestiller-Udfører-Modtager = ordering-delivering- 
receiving). Home care services are ordered by a visitation function that has the task of assessing the needs of users. Visitation thus serves as the public authority that decides which services individual users are entitled to, and operations (or other, private service providers) then makes the delivery. The new governance model does not tinker with this basic principle. Instead, it reduces the number of specific units (work tasks) designated in the management of home care while introducing visiting blocks as a more open and trusting means of governing without compromising control.

Before the reform, the management of home care specified no less than 79 individual units/deliveries and home care professionals had to register, on a handheld computer (PDA Personal Digital Assistant), their check-in time for work, their coming and going in each user's home and their lunch time. In internal communications, the new governance model has been presented as a radical administrative simplification, and the transition has been framed as putting an effective end to the 'time and control tyranny' in home care. The time tyranny has ended in the sense that home care professionals no longer have to register how they spend their time. They have been relieved of this administrative burden and this should better enable them to be mentally present, caring and attuned to the individual needs of users - apart from actually having more time for the core task of delivering care.

Visiting blocks embrace the whole service encounter and this means that home care professionals have been given more freedom to manoeuver and exercise their professional expertise and judgment. Visiting blocks basically refer to the time of day when service is delivered: morning, middle of the day and evening. However, depending on the needs of users, the content stipulated in visiting blocks can be 'light', 'moderate' or 'comprehensive'. Moreover, it also distinguishes between 'early' and 'late' evening and makes it possible to specify special 
needs for support in visiting blocks (particularly for elderly people suffering from dementia or other cognitive ailments). When all is accounted for, the new model defines 19 visiting blocks. Included in visiting blocks are services such as helping the user get dressed and move around, personal hygiene, toilet visits, baths, light cleaning and wage disposal, serving of breakfast and other meals, along with help in eating and drinking. On top of this, a number of services are given specifically to users (i.e. they are not integrated in visiting blocks). There are 21 of these in all and they include help with medicine (taking of medicine and opening of medicine bags), transportation outside the home, shopping and social visits and telephone calls. In addition, many of the deliveries included in visiting blocks can also be given as specific services if users have additional needs that cannot be accommodated within the time span of visiting blocks. What has been accomplished, in sum, is akin to a 50\% reduction in managed units: from 79 (services) to 19 (visiting blocks) +21 (services) $=40$.

With this new model, work plans as a means of control are not discarded, but home care professionals are given considerable leeway with regard to how they spend their time in users' homes: They can choose to prioritize one task over another, or they can choose to spend more time with one user at the cost of others on any given day. In all, however, they have not been given more time to do their job, which arguably puts pressure on their ability to manage their own time, avoid giving favourable treatment to particular users, etc. Instead of time registration, home care professionals now have to make a daily and weekly work plan and coordinate this with users based on their needs. This reflects how the visiting blocks are also meant to accommodate better user dialogue and inclusion of citizens. The work plan is an administrative burden on employees, but serves an important professional purpose as it should make it easier for 
temporal workers to do a good job, i.e. one that is attuned to the needs and expectations of the individual user.

It is strongly emphasized by interviewees that the easiest part of visiting blocks is implementing it as a new structure. The hard part has to do with the process of change in organizational culture that must follow. This is not only a matter of home care professionals adjusting themselves to a new, more self-managing mind set. It is also a matter of redefining what the management of home care is about, also in operations. In other words, it involves creation of new managerial and employee identities.

\section{Management processes}

Visiting blocks is supposed to allow managers to have more of a professional focus without losing control. This is an important part of trust reform in home care as it entails an increased reliance on professional judgment calls and new uncertainties and responsibilities associated herewith. As part of this effort, managers are supposed to engage more closely with employees and how they do their job. This includes occasional observation of how home care is being carried out in users' homes. Ideally, employees should perceive this supervision as part of a professional dialogue, but it can also be perceived as undue interference, signalling distrust and an unwelcome need to look over the shoulder of employees. There is a challenge here for managers to (re)assert themselves in terms of their professional expertise - after many years in a system preoccupied with administrative paper work, documentation and control. Part of the learning process has to do with creating a new, more professional dialogue between managers and employees that is based on trust and a mutual understanding of the new governance model and its possibilities. 
The process of implementing the new governance model is bound to proceed differently in different parts of the organization. As mentioned, home care consists of five local units and 40 operational work groups with 40 group leaders. The local units cover different boroughs and the different work groups and their leaders and employees to some extent reflect the different cultures and user profiles found in different parts of a big city. No central efforts are made to streamline - or control - how different managers cope with the challenges related to trust in regard to their employees and there is an acceptance that there can be strength in diversity.

Different managers have different prerequisites for succeeding with this endeavour. The new model signals a higher degree of trust in relation to home care professionals and it opens a space for managers to manage in a manner that is more conducive to the creation of trusting relationships. However, it is up to the individual managers to figure out how best to fill this space and balance trust and control. There is a high level of awareness in the organization that managers are not automatically imbued with trust just because trust initiatives and trust reform are on the organizational agenda. They will each have to deserve the trust of employees. Some managers have not been able to live up to the new professional requirements. In the words of a home care manager: "There are managers who have not been able to live up to [new requirements], and it has very much been related to the trust agenda. Those skilful managers that we found very useful 10-15 years ago, who were very militaristic: 'this is what you must do, now just go out and do it', some of those we've had to get rid of. There is no doubt that there is a need for managers with professional capacity, who can, perhaps through delegation, lift the professional task." This is indicative of how the new model has served to create new managerial roles and identities. It comes with a new set of professional requirements and demands for 
managerial action that are far from stable. This creates new challenges for managers to navigate in the nexus of trust and control. The same goes for employees in operations.

\section{Employee roles and identities}

Speaking of employee perceptions and behaviours we are, to iterate, partly relying on managerial accounts and partly focusing on structural implications of the reform. Among employees, the new model has generally been a success story as it represents a welcome softening of the stronghold of NPM that comes with promises of better performance, better care and happier and more motivated employees. Many home care professionals experience more freedom in their daily work life. This makes it easier for them to be mentally present and attuned to the needs of users. Minutes from internal meetings regarding reform efforts suggest that home care employees find it highly important that management has an in-depth understanding of their daily work and challenges - in order to be able to provide the necessary support. According to one employee: "Management differs a lot - it is important that management understands our profession and the challenges we are faced with in our daily work. That they understand when we need assistance. It was difficult earlier, when I had a manager with a different professional background. Back then, they often did not understand why I said what I did. It is completely different now." According to another employee: "It is a problem if our challenges in the unit are not understood by the administration and by the board of directors. If those who make the decisions do not understand the professional content and the way we work." Hence, professional qualifications and dialogue are vital requirements for management/managers to appear credible and trustworthy among employees. The importance of openness is also strongly emphasized. An employee conveys the following experience: "When we come to our manager with something, 
and she is looking into the screen, she always turns and listens to what we have to say.

Sometimes we talk, or she says that we have to talk about it later. But she will always listen. The door may be closed, but it is not so closed that it cannot be opened". However, the implementation of visiting blocks is not necessarily associated with trust as such - that seems to depend on how strong relations are to the immediate supervisor/manager. To quote an internal consultant: "The trust agenda lives inside different policies and strategies, and it may be that individual employees do not realize this unless you communicate that there is actually a lot of the trust agenda in this [referring to a particular policy].” According to the same consultant, scepticism has been detected among some employees, whose reaction is related to negative experiences of prior reform efforts. This is another indicator that trust-based forms of management may not be experienced as such - and may not be successful in creating trust.

With freedom comes responsibility. The event of visiting blocks and the reconfigured relation between operations and visitation mean that home care professionals are exposed to new professional demands. A home care manager explains the difference: "If you're told, 'now you go out and empty the trash, do the dishes, give the user a bath and dress her'. If you're told that as a helper, it only requires that you go out and do these four things, and apart from that you can put on blinders and go on to the next user. But you can't do that with the trust agenda and the block system today. It is completely impossible. You have to go out, have a look and see what the user needs today, and that requires other competencies." Apart from delivering care, the job of home care professionals is now also to continually observe, register and communicate the changing needs of users. The new model has thus added complexity and created a more demanding job, and this is very much experienced in the organization. The new model implies a further professionalization of home care (other reforms have also been pulling in this direction), 
making employees with longer education in social care and health more valuable compared to low-skilled workers. Home care is often associated with routine and manual tasks, but the new model adds an element of knowledge work to the list of tasks and skills required. The knowledge work not only requires certain professional qualifications, it also requires ability to communicate professional judgements and argue your case. Many low-skilled employees are finding these requirements very challenging, and management is making an urgent call for these employees to further educate themselves, train and upgrade their skills. Better educated employees are better equipped to make professional judgment calls, they can act as nurses, when there is a need for it, and in some cases they have also been given the task of observing homes that are covered by low-skilled colleagues.

While the new model excludes some, it can also support new forms of inclusion and responsibility. Home care is subject to budget cuts and it is therefore imperative to stay within the budget in the different parts of the organization. In one working group, the employees made a common vow to avoid (costly) use of temporary help and to cover for each other when a colleague called in sick. They succeeded in bringing the use of temps down to zero, and this can be seen as an example of how strong social relations and holistic thinking (albeit at a local level) can have positive performance and economic effects. Although this initiative is not directly a result of the trust reform, it reflects a kind of responsible professionalism that the new model is meant to promote. Control is not sidelined, but formal control is supplemented by local social control.

\section{Relations between visitation and operations}


On a more conflictual note, the reform has shown signs of increasing tensions between visitation (recognized as a control function) and operations (recognized as a function in need of more trust) by tipping the scales and altering the power balance between the two. Arguably, the trust reform makes it more legitimate for operations not only to call for more time to do a proper job with users, but also to challenge the NPM-dictated authority of visitation in home care altogether.

The BUM model installs a principal-agent relationship between visitation and operations. In the resulting division of labor, it is not the function of visitation to have trust in home care employees. It is to supervise and control the quality and delivery of services according to extant rules and regulations. As the now former head of visitation put it: "There are many different approaches. Mine is one of public authority that is political and economic. What is it that citizens require, and what political objectives are at stake (...) I'm sitting across from people from home care or training centres with very different approaches to care". She also mentioned how group leaders would use trust as a sort of 'club' (weapon) to legitimize the need for more time to do their job, thus using trust as an argument in discussions that, according to her, had nothing to do with trust, but was all about economic and professional matters. This is reflective of how visitation is not supposed to have a holistic outlook on the organization of home care. It is supposed to close focus on each discrete service offering and the means by which it can best be delivered. However, this conflictual view does not adequately reflect how relations between visitation and operations have developed after the implementation of visiting blocks.

Both in visitation and operations managers and employees have had to adapt themselves to the new model. In operations, employees have gone through a learning process of finding out how best to work with visiting blocks, while in visitation they have gone through a process of adapting to the new, less controlled conditions for delivery of services. As expressed by one 
home care manager, "time has been helpful". Even if the BUM model creates oppositional interests between the parties, time has seen fewer conflicts and more flexibility and tolerance emerge in relations between visitation and operations; thus, there has been a sharp reduction in the correction of services that individual users are entitled to. This has been supported by a change of management in visitation. The new manager has come with a greater belief that trust can be an economic benefit for the organization, and a greater belief in the ability of home care employees to lift their new responsibilities. This has resulted in the development of greater mutual understanding, recognition and respect for each other's ways of doing things. These effects shows how categorical differences that comes with particular models of governing can be softened and to some extent reconciled in practice, and thus point to the need for a processbased, relational understanding of the trust-control nexus.

\section{Discussion}

We have argued that there are four different modes of explaining the interaction between trust and control in organizational processes. While the substitution view can certainly be valid and relevant as a mode of explanation in many contexts, we have argued that it is lacking when it comes to capturing the processes set in motion by efforts to de-bureaucratize modern public sector organizations. In the Danish case, articulations on all policy levels, ranging from central and local government to collective agreements indicate that trust is not meant to function as a substitute for control, but as a complement to extant uses of rules and contracts. The home care case provides further empirical support for this general finding.

The complementary view of trust and control suggests that both are vital for the effective functioning of organizations and can support each other in a symbiotic relationship. This 
perspective allows us to speak of a certain mix or balance being accomplished between trust and control. It is assumed that trust and control are separate from each other and manifest in relatively stable forms. In the case of home care, the BUM model represents control, whereas the free space provided by visiting blocks represents trust. However, this would be a short hand and reductionist reading of the case, in particular with regard to the trust side of the equation. The new governance model constitutes a form of de-bureaucratization that partakes in creating new working conditions that are not necessarily associated with trust by employees in operations. It also creates new spaces for home care managers to lead based on trust, but it is left up to individual managers to fill this space and not all are up to the task. What we find here are not stable identities, but rather open processes. Furthermore, the control side has also shown itself to be somewhat plastic. This leads us to the mutually constitutive view. The constitutive view provides a more dynamic and interactive understanding of the trust-control nexus. Whereas the complementary view focuses on co-presence, the constitutive view focuses on processes of coevolvement as trust and control shape and are being shaped by one another over time. This allows us to more fully embrace a process view and see how identities are not stable, but prone to change over time. In the case of home care, most notably, we can see how the oppositional interests between the visitation function (control) and operations (trust) cannot be taken for granted. Mutual adjustments are taking place over time as a result of social interaction; positive learning processes have taken place, involving employees and managers - with a change of management providing further support for this development. Furthermore, relations between trust and control are constantly negotiated. We can thus see how controllers can become more trusting and believers in trust can become more tolerant towards control. However, it is still 
assumed that trust and control form separate entities that can more or less be determined beforehand.

With the emergent view we propose that it is meaningful, in some instances, to venture beyond this assumption and more fully embrace the importance of temporality for the analysis of trust (and control). With this perspective, the starting point is neither trust and control as stabilized (complementary) or somewhat destabilized (constitutive) entities, but the event. This starting point allows us to pose the question of how trust and control emerge, and, just as importantly, to further explore what is meant by trust and what is meant by control in the organization. The pivotal event of our analysis is trust reform in home care (i.e., the new governance model), but as we have shown this has had a number of intended or unintended relational and process effects that constitute further events. This multiplying of events enable trust and control to emerge in ways that cannot be determined beforehand and that can be highly different.

This openness comes to the fore in the implementation of the new governance model, which, although motivated by the municipal trust agenda, by no means constitute an implementation of trust in a uniform manner. Instead, as we have seen, it creates multiple open spaces for trust and control to emerge and be negotiated between organizational members in novel ways. With regard to managers and management processes, an illustrative example is the event of supervision in home care. We cannot attribute an unequivocal trust or control value to supervision beforehand. The relationship between trust and control emerges out of individual encounters between managers and employees and is bound to be perceived differently by the involved parties. For employees, visiting blocks comes with new freedoms as well as new responsibilities. It creates a more demanding job that is also meant to be more fulfilling for 
employees. How these altered working conditions translate into trust and control is an empirical question that calls for more in-depth study. The point is that a trust initiative cannot be determined beforehand as trust, not least considering that many home care employees do not explicitly associate visiting blocks with trust. With regard to relations between visitation and operations, insights from the constitutive view can be copied into the emergent view. The point being, to iterate, that the relationship between the two parties cannot be assumed beforehand, but is dependent on situational encounters. It emerges from events, from interactions between employees and resulting polycentric learning processes. What the emergent view stresses, on top of the insights provided by the constitutive view, is the need to further multiply our understanding of how processes take place. Instead of providing broad analyses of mutual accommodation between trust and control, we need to look into the multiple trust-control nexuses that emerge in different and singular ways from multiple events in the organization. It is an empirical question not only how trust and control relate to one another, but also how they emerge as difference within organizations.

Our research follows the path of other studies that have shown how trust and control can act as complements in public sector areas such as regulation (Six, 2013) and public planning projects (Edelenbos \& Eshuis, 2012). We have argued that organizational context matters, at least indirectly, when we talk about generation and maintenance of social/interpersonal trust (Blunsdon \& Reed, 2003; Six \& Sorge, 2008), and that we therefore need to consider the particular ways in which trust (and control) is embedded in systems and models of governance in the public sector. In public sector organizations the call for (internal) trust has emerged as a pushback against the sometimes excessive bureaucratization associated with the Neo-Weberian state (Bouckaert, 2012b) and, in particular, New Public Management with its emphasis on 
market-based control, disaggregation and distrust (Hood \& Dixon, 2015a; Van de Walle, 2011). The negative effects of NPM on the motivation of public sector employees have been addressed in the literature on public service motivation and motivation crowding (see Bozeman \& Su, 2015; Frey, 1994; Frey \& Jegen, 2000). While New Public Governance is the programmatic term for a more trust-based and relational view of public management and organization (Osborne, 2006), we have tried to venture beyond programmatics in order to explore the actual, micro-level effects of a reform effort driven by a trust agenda. While we recognize the need to highlight the deliberate mechanisms by which social trust can be created in organizations (Six \& Sorge, 2008), and consider our analysis to be supportive of relational ideals of organization (Gittell \& Douglass, 2012), we have tried to show that trust-based reform can have multiple relational effects in practice, and that these effects cannot be fully contained even within a complementary view of trust and control. Considering the empirical limitations of our study, this finding calls for further validation in future research.

\section{Conclusion}

We have noticed a dearth of research addressing relationships and tensions between trust and control in relation to public sector organization and management. Widespread discontentment with the ways and means of New Public Management provides a fertile ground for studies of trust as an institutionally embedded phenomenon. We have provided one such study based on trust reform efforts in Denmark. The Danish case can be considered special or extreme considering that Denmark is known to be a high trust country, but the experience of NPM in the public sector is, albeit in varied forms, shared across Western countries in particular and provides a starting point for a more general discussion of how public organizations best can function and 
develop. While the primary aim of this paper has been to contribute to the analytical understanding of trust reform as process, it also reflects a political concern regarding the future development of the public sector. If the discontentment over NPM is to be transformed into constructive and successful alternatives then one-sided attention to trust seems a naïve way to go. It is important to recognize the complexity of the trust and control relationship and to understand the underlying mechanics.

The theoretical-analytical implication of our findings is that there is a need for more process-based studies of how trust-based reform efforts - or managerial efforts to promote trust operate in practice and the manifold events by which they come into being and become meaningful (or not) for organizational actors. The practical implication has to do with the expectations we may have toward trust-based reforms (or trust-based initiatives). Some sceptics may consider trust reform in the public sector a virtual impossibility. If we speak of trust as substitution of control, this is arguably a warranted skepticism. If we start to embrace a complementary or emergent view of the trust-control nexus much less so. To consider trust and control as emergent features of organization, instead of more or less stable identities, is to argue for the value of experimentation and tolerance toward difference and openness in processes. We should not expect or wish trust-based reform to proceed in a uniform manner or to produce standardized results, but rather consider it as a means to engage and enable public managers and employees in finding new and better ways to balance and negotiate the meaning of trust and control. This can be an important part of creating a stronger and more productive public sector.

\section{Acknowledgement}


The authors wish to thank the editors and two anonymous reviewers for their valuable feedback and important contributions to the development of this article. We also wish to thank Rasmus Hagedorn-Olsen (MSc, Copenhagen Busines School) for his contribution to the gathering of empirical data for this study. The article is partly based on the same data as Vallentin \& Thygesen (2016), but provides an extended and updated analysis of the effects of trust reform in home care.

\section{References}

Adler, P.S \& Kwon, S-W. (2002). Social Capital: Prospects for a New Concept. Academy of Management Review, 27(1), 17-40.

Alvesson, M. \& Skjöldberg, K. (2010). Reflexive Methodology. New Vistas for Qualitative Research, 2. ed. Great Britain: Sage Publications.

Andrews, R. (2010). Organizational social capital, structure and performance. Human Relations, 63(5), 583-608.

Andrews, R. \& Brewer, G.A. (2013). Social Capital, Management Capacity and Public Service Performance, Public Management Review, 15(1), 19-42.

Bachmann, R. (2001). Trust, power and control in trans-organizational relations. Organization Studies, 22(2), 337-365.

Bachmann, R. (2011). At the crossroads: Future directions in trust research. Journal of Trust Research, 1(2), 203-213.

Baier, A. (1986). Trust and Antitrust. Ethics, 96(2), 231-260.

Bijlsma-Frankema, K. \& Costa, A. C. (2005) Understanding the trust-control nexus. International Sociology, 20(3), 259-282. 
Blunsdon, B. \& Reed, K. (2003). The Effects of Technical and Social Conditions on Workplace Trust. International Journal of Human Resource Management, 14, 12-27.

Bouckaert, G. (2012a). Reforming for Performance and Trust: Some Reflections. The NISPAcee Journal of Public Administration and Policy, V(1), 9-20.

Bouckaert, G. (2012b). Trust and Public Administration. Administration, 60(1), 91-115.

Bradach, J. \& Eccles, R. (1989). Price, authority, trust and control: From ideal types to plural forms. American Review of Sociology, 15, 97-118.

Bromley, P. D. (1990). A philosophy of science for the study of individual cases. Counselling Psychology Quarterly, 3(3), 299-307.

Chia, R. \& Langley, A. (2004). The first Organization Studies summer workshop: Theorizing process in organizational research (call for papers). Organization Studies, 25(8), 1486-1488.

Clarke, J, \& Newman, J. (1997). The Managerial State. Power, Politics and Ideology in the Remaking of Social Welfare. Great Britain: Sage Publications.

Coletti, A. L., Sedatole, K. L. \& Towry, K.L. (2005). The effect of control systems on trust and cooperation in collaborative environments. The Accounting Review, 80(2), 477-500.

Costa, A. C. \& Bijlsma-Frankema, K. (2007). Trust and control interrelations - New perspectives on the trust-control nexus. Group \& Organization Management, 32(4), 392-406.

Das, T. K. \& Teng, B-S. (1998). Between trust and control: Developing confidence in partner cooperation in alliances. Academy of Management Review, 23(3), 491-512.

Das, T. K., \& Teng, B-S. (2001) Trust, control, and risk in strategic alliances: An integrated framework. Organization Studies, 22, 251-283.

Den danske regering [The Danish Government] (2011) Et Danmark, der står sammen. Regeringsgrundlag, oktober 2011. Available from: 
http://www.stm.dk/publikationer/Et_Danmark_der_staar_sammen_11/Regeringsgrundlag_okt _2011.pdf

Dubois, A., \& Gadde, L.E. (2002). Systematic combining: an abductive approach to case research. Journal of business research, 55(7), 553-560.

Edelenbos, J. \& Eshuis, J. (2012). The interplay between trust and control in governance processes: A conceptual and empirical investigation. Administration \& Society, 44(6), 647674.

European Commission (2017). Trust at Risk: Implications for EU Policies and Institutions. Brussels: European Commission, Directorate-General for Research and Innovation.

Frey, B. (1994). How Intrinsic Motivation is Crowded Out and In. Rationality \& Society, 6(3), 334-352.

Frey, B. \& Jegen, R. (2000). Motivation Crowding Theory: A Survey of Empirical Evidence. CESifo. Working Paper, No. 245, Ifo Institute - Leibniz Institute for Economic Research at the University of Munich.

Fukuyama, F. (1995). Trust: The Social Virtues and the Creation of Prosperity. England: Hamish Hamilton.

Gargiulo, M. \& Ertug, G. (2006). The dark side of trust. In R. Bachmann \& A. Zaheer (Eds.), Handbook of Trust Research (pp. 165-186). Cheltenham: Edward Elgar.

Gittell, J.H. \& Douglass, A. (2012). Relational Bureaucracy: Structuring Reciprocal Relationships into Roles. Academy of Management Review, 37(4), 709-733.

Gouillart, F. \& Hallett, T. (2015). Co-Creation in Government. Stanford Social Innovation Review, Spring issue, 40-47. 
Le Grand, J. (2010). Knights and Knaves Return: Public Service Motivation and the Delivery of Public Services. International Public Management Journal, 13(1), 56-71.

Grey, C. \& Garsten, C. (2006). Trust, control and post-bureaucracy. Organization Studies, 22(2), 229-250.

Hernes, T. (2008). Understanding Organization as Process - Theory for a Tangled World. London: Routledge.

Hernes, T. (2014). A process theory of organization. Croydon: Oxford University Press.

Hood, C. \& Dixon, R. (2015a). A Government that Worked Better and Cost Less? Evaluating Three Decades of Reform and Change in UK Central Government. Croydon: Oxford University Press.

Hood, C. \& Dixon, R. (2015b). What We Have to Show for 30 Years of New Public Management: Higher Costs, More Complaints. Governance: An International Journal of Policy, Administration and Institutions, 28(3), 265-267.

Høyer, H.C. \& Mønness, E. (2016). Trust in public institutions - spillover and bandwidth. Journal of Trust Research, 6(2), 151-166.

Inkpen, A.C. \& Currall, S.C. (2004). The Co-Evolution of Trust, Control, and Learning in Joint Ventures. Organization Science, 15, 586-599.

Jun, J.S. (2009). The Limits of Post-New Public Management and Beyond. Public Administration Review, January-February, 161-165.

Khodyakov, D. (2007) Trust as a process: A three-dimensional approach. Sociology, 41(1), 115132. 
Krouwel, A. \& Abts, K. (2007). Varieties of Euroscepticism and Populist Mobilization: Transforming Attitudes from Mild Euroscepticism to Harsh Eurocynicism. Acta Politica $42(2-3), 252-270$.

Københavns Kommune [The Municipality of Copenhagen] (2012) Budget '13. København, Københavns Kommune.

Langley, A. (1999). Strategies for theorizing from process data. Academy of Management Review, 24(4), 691-710.

Langley, A. (2009). Studying processes in and around organizations. In D.A. Buchanan \& A. Bryman (Eds.), The Sage Handbook of Organizational Research Methods (pp. 409-429). London: Sage.

Lewis, J.D. \& Weigert, A. (1985). Trust as a social reality. Social Forces, 63(4), 967-985.

Long, C.P. \& Sitkin, S.B. (2006). Trust in the balance: How managers integrate trust-building and task control. In R. Bachmann \& A. Zaheer (Eds.), Handbook of Trust Research (pp. 87106). Cheltenham: Edward Elgar.

Luhmann, N. (1979). Trust and Power. New York, John Wiley.

Mayer, R.C., Davis, J.H. \& Schoorman, F.D. (2006). An Integrative Model of Organizational Trust. Academy of Management Review, 20(3), 709-734.

Möllering, G. (2005). The trust/control duality. International Sociology, 20(3), 283-305.

Möllering, G. (2006). Trust: Reason, Routine, Reflexivity. UK: Emerald.

Möllering, G. (2013). Process views of trusting and crises. In Bachmann, R. \& A. Zaheer (Eds.), Handbook of Advances in Trust Research (pp. 285-305). Cheltenham: Edward Elgar.

OECD (2017). Trust and Public Policy: How Better Governance Can Help Rebuild Public Trust. Paris: OECD Publishing. 
Oomsels, P. \& Bouckaert, G. (2014). Studying interorganizational trust in public administration: A conceptual and analytical framework for administrational trust. Public Performance \& Management Review, 37(4), 577-604.

Osborne, S.P. (2006). The New Public Governance. Public Management Review 8(3), 377-387.

Pollitt, C. \& Bouckaert, G. (2011). Public Management Reform: A Comparative Analysis - New Public Management, Governance, and the Neo-Weberian State, $3^{\text {rd }}$ edition. Oxford: Oxford University Press.

Robson, C. (2002). Real World Research, 2nd. Edition. Malden: Blackwell Publishing.

Rousseau, D.M., Sitkin, S.B., Burt, R.S: \& Camerer, C. (1998). Not so Different after All: A Cross-Discipline View of Trust. Academy of Management Review, 23(3), 393-404.

Sitkin, S. (1995). On the positive effect of legalization on trust. Research on Negotiation in Organisations, 5, 185-217.

Sitkin, S. \& George, E. (2005). Managerial trust-building through the use of legitimating formal and informal control mechanisms. International Sociology, 20(3), 307-338.

Six, F. (2013). Trust in regulatory relations. How new insights from trust research improve regulation theory. Public Management Review, 15(2), 163-185.

Six, F., \& Sorge, A. (2008). Creating a high-trust organization: an exploration into organizational policies that stimulate interpersonal trust building. Journal of Management Studies, 45(5), 857-884.

Skinner, D. \& Spira, L.F. (2003). Trust and control - symbiotic relationship? Corporate Governance, 3(4), 28-35. 
Smets, L. P. M., van Oorschot, K.E. \& Langerak, F. (2013). Don't trust trust: A dynamic approach to controlling supplier involvement in new product development. Journal of Product Innovation Management, 30(6), 1145-1158.

Vallentin, S. \& Thygesen, N. (2016). Trust, Control and Public Sector Reform. In: S. Jagd \& L. Fuglsang (Eds.), Trust, Organizations and Social Interaction. Studying Trust as Process within and between Organizations (pp. 283-299). Croydon: Edward Elgar.

Van de Walle, S. (2011). New Public Management: Restoring the Public Trust through Creating Distrust? In T. Christensen \& P. Lægreid (Eds.), Ashgate Research Companion to New Public Management (pp. 309-320). Aldershot: Ashgate.

Van de Walle, S. (2017). Trust in public administration and public services. Ch 7 in European Commission (2017), Trust at Risk: Implications for EU Policies and Institutions (pp. 118128). Brussels: European Commission, Directorate-General for Research and Innovation.

Van de Walle, S., Van Roosbroek, S. \& Bouckaert, G. (2008). Trust in the public sector: Is there any evidence for a long-term decline? International Review of Administrative Sciences, 74(1), 45-62.

Weibel, A. (2007). Formal control and trustworthiness - Shall the twain never meet. Group \& Organization Management, 32(4), 500-517.

Weibel, A., Den Hartog, D.N., Gillespie, N. Searle, R., Six, F. \& Skinner, D. (2016). How Do Controls Impact Employee Trust in the Employer? Human Resource Management, 55(3), 437-462.

Welch, C. \& Paavilainen-Mäntymäki, E. (2014). Putting process (back) in: Research on the internationalization process of the firm. International Journal of Management Reviews, 16, 223. 
Yin, R.K. (2014). Case study research: design and methods, $5^{\text {th }}$ Edition. Thousand Oakes: Sage.

Zucker, L.G. (1986). Production of trust: Institutional sources of economic structure, 1849-1920. Research in Organizational Behavior, 8, 53-111. 